\title{
DMF (2,5-dimetylofuran) jako perspektywiczne biopaliwo drugiej generacji do silników o zapłonie iskrowym
}

\section{Wprowadzenie}

Malejące zasoby paliw kopalnych oraz związane z eksploatacją paliw globalne ocieplenie powodują, że w stosunkowo niedalekiej przyszłości niezbędne będzie sięganie do „zrównoważonych” zasobów energii. Aby jednak paliwo nadawało się do wykorzystania w transporcie musi posiadać specyficzne właściwości fizykochemiczne, odpowiadające wymuszeniom silników, które pozwolą na jego wydajną dystrybucję, magazynowanie i spalanie.

Nowym i perspektywicznym rozwiązaniem w zakresie technologii wytwarzania biopaliw jest katalityczna strategia produkcji 2,5-dimetylofuranu z fruktozy (węglowodanu otrzymywanego wprost z biomasy, lub poprzez izomeryzację z glukozy), który wykazuje bardzo dobre właściwości paliwowe. W porównaniu z etanolem, DMF ma wyższą gęstość energetyczną (o 40\%), wyższy punkt wrzenia $($ o $20 \mathrm{~K})$ i nie jest rozpuszczalny w wodzie. Przewiduje się, że technologia otrzymywania DMF stworzy nowe ścieżki w przekształcaniu obfitych, odnawialnych zasobów biomasy $\mathrm{w}$ transportowe paliwa płynne i nieodzownie może zmniejszyć zależność Polski od ropy naftowej.

\section{Podstawowe właściwości DMF}

(DMF) 2,5-dimetylofuran jest pochodną furanu, o wzorze stechiometrycznym $\mathrm{C}_{6} \mathrm{H}_{8} \mathrm{O}$ i masie molowej $96,12892 \mathrm{~g} / \mathrm{mol}$. Z punktu widzenia zastosowań może być komponentem paliw silnikowych, bądź też występować jako samodzielne paliwo, DMF posiada szereg właściwości uznanych za korzystne:

1 Oznaczenie numeryczne przypisane substancji chemicznej przez amerykańską organizację Chemical Abstracts Service (CAS), pozwalające na identyfikację substancji.

Oznaczenie numeryczne przypisane substancji chemicznej w Europejskim Wykazie Istniejacych Substancji o Znaczeniu Komercyjnm (EINECS - ang. European Inventory of Existing Chemical Substances). 
- jest nietoksyczny (CAS 625-66-5) ${ }^{1}$, (EINECS 210-914-3)2;

- nie zawiera siarki, fosforu oraz metali;

- nie zawiera benzenu i wielopierścieniowych węglowodorów aromatycznych (WWA);

- jest całkowicie rozpuszczalny w węglowodorach oraz innych związkach tlenowych, zawartych w składzie paliw silnikowych;

- jest praktycznie nierozpuszczalny w wodzie;

- jego wartość opałowa jest o 40\% większa od wartości opałowej etanolu i zbliżona do wartości opałowej benzyn silnikowych;

- może być stosowany jako rozpuszczalnik wielu substancji oraz składnik lakierów;

- jest stabilny chemicznie.

Podstawowe właściwości DMF zawarto w tabeli 1.

Tabela 1. Podstawowe właściwości DMF

\begin{tabular}{|c|c|c|}
\hline PARAMETR & JEDNOSTKA & WLAŚCIWOŚĆ \\
\hline Numer CAS & - & {$[625-86-5]$} \\
\hline Numer EINECS & - & [210-914-3] \\
\hline Barwa & & Żółta \\
\hline Zapach & & aromatyczny \\
\hline Stan skupienia & - & płyn (ciecz) \\
\hline Główne zagrożenia & & łatwopalność \\
\hline Masa molowa & $\mathrm{g} / \mathrm{mol}$ & 96,14 \\
\hline Gęstośćc & $\mathrm{g} / \mathrm{cm} 3$ & 0,8883 \\
\hline \emperatura wrzenia & ${ }^{\circ} \mathrm{F}\left({ }^{\circ} \mathrm{C}\right)$ & $200,3(93,5)$ \\
\hline 囚emperatura krzepnięcia & ${ }^{\circ} \mathrm{F}\left({ }^{\circ} \mathrm{C}\right)$ & $-81,0(-62,8)$ \\
\hline \emperatura zapłonu & ${ }^{\circ} \mathrm{F}\left({ }^{\circ} \mathrm{C}\right)$ & $30,2(-1)$ \\
\hline Rozpuszczalność w wodzie & $\mathrm{mg} / \mathrm{ml}$ & $<1$ \\
\hline Rozpuszczalność w węglowodorach & & nieograniczona \\
\hline $\begin{array}{l}\text { Prężnosść par w temperaturze: } \\
72,0^{\circ} \mathrm{F}\left(22,2^{\circ} \mathrm{C}\right) \\
124^{\circ} \mathrm{F}\left(51,1^{\circ} \mathrm{C}\right) \\
167^{\circ} \mathrm{F}\left(75^{\circ} \mathrm{C}\right) \\
\end{array}$ & mm sł.Hg & $\begin{array}{r}53,0 \\
174 \\
404 \\
\end{array}$ \\
\hline Współczynnik załamania światła & & $1,44-1,442$ \\
\hline Gęstość energetyczna & $\mathrm{MJ} / \mathrm{kg}$ & 42 \\
\hline Liczna oktanowa badawcza (RON) & & 119 \\
\hline
\end{tabular}

DMF może być sklasyfikowany jako biopaliwo drugiej generacji z uwagi na to, że w procesie swojej produkcji wymaga surowców bogatych w lignocelulozę,

3 W temperaturze $20^{\circ} \mathrm{C}$ 
skrobię i inne polisacharydy, których dostatek można odnaleźć w biomasie oraz w masie odpadowej wielu gałęzi przemysłowych takich jak przemysł drzewny, spożywczy, papierniczy, zbożowy i gorzelniany.

DMF określa się jako perspektywiczny zamiennik, stosowanego aktualnie etanolu. Etanol jest jedynym odnawialnym paliwem płynnym produkowanym na wielką skalę. Jednak z punktu widzenia właściwości paliwowych ma on kilka wad. Przede wszystkim ma relatywnie małą gęstość energetyczną przez co potrzebny jest wtrysk odpowiednio większej ilości paliwa celem wyprodukowania konkretnej ilości energii elektrycznej. Kolejnym minusem jest jego wysoka lotność spowodowana względnie niską temperaturą wrzenia. Następna wada etanolu to wysoka podatność na zanieczyszczenie poprzez wysoką absorpcję wody z atmosfery. Również fakt, że etanol wymaga wysokoenergetycznego procesu destylacji celem oddzielenia go od wody, stanowi złą właściwość tego związku jako paliwa.

W porównaniu do etanolu DMF ma znacznie korzystniejsze właściwości fizykochemiczne, z punktu widzenia zastosowania go jako paliwa silnikowego. Jego rozpuszczalność w wodzie jest bliska zeru, a więc nie grozi mu możliwość zanieczyszczenia wodą. Jego gęstość energetyczna jest o $40 \%$ większa względem etanolu, co sprawia, że DMF staje się godnym konkurentem dla benzyny. Demperatura wrzenia dimetylofuranu jest o prawie $20^{\circ} \mathrm{C}$ wyższa, co powoduje, że jego lotność jest niższa od lotności etanolu. Etap odparowania DMF w procesie jego otrzymywania wymaga jedynie jednej trzeciej ilości energii zużytej na odparowanie etanolu produkowanego poprzez proces fermentacji. Ponadto dimetylofuran jest związkiem stabilnym pod względem chemicznym, co pozwoli na jego magazynowanie przez dłuższy czas.

W rozważaniach nad możliwościami i celowością uruchomienia produkcji i zastosowań DMF jako komponentu paliw silnikowych, należy brać pod uwagę jego zalety i wady. DMF, jako paliwo ma następujące zalety:

- DMF można produkować z odpadowej celulozy oraz odpadowej skrobi, a także $z$ innych surowców odnawialnych, zawierających polisacharydy oraz cukry;

- DMF można dodawać do benzyny węglowodorowej jako komponent tlenowy (dopuszczalne proporcje mieszania nie są jeszcze ustalone). Ma on wysoką liczbę oktanową oraz temperaturę wrzenia i topnienia, co czyni go szczególnie odpowiednim komponentem paliw do silników o zapłonie iskrowym;

- stosowanie DMF w składzie benzyny silnikowej nie wymaga żadnych zmian w konstrukcji silników, układów zasilania oraz systemów dystrybucji;

- DMF ma korzystne od etanolu właściwości energetyczne (wartość opałową i gęstość energii).

Wady DMF jako paliwa są następujące:

- technologie produkcji DMF są na bardzo wczesnym etapie rozwoju, a ich implikacje finansowe nie są jeszcze znane; 
- DMF może działać chemicznie na niektóre, powszechnie stosowane uszczelnienia i inne elementy pojazdu, wykonane $\mathrm{z}$ tworzyw sztucznych, stąd powstaje problem trwałości układu zasilania i niektórych elementów układu dystrybucji;

- aktualnie brak jest specyfikacji (normy) na DMF jako komponentu paliwa. Może również okazać się niezbędne opracowanie specyficznych norm czynnościowych na niektóre metody badań lub pobieranie próbek;

- w praktyce nie są dostępne publikacje, dotyczące rezultatów testów silnikowych oraz testów pojazdów w cyklach jezdnych, a także badań eksploatacyjnych na paliwach zawierających DMF. Należy się więc liczyć z koniecznością przeprowadzenia takich badań;

- brak rezultatów badań oceny wpływu DMF na emisje składników toksycznych do atmosfery;

- brak ocen emisji gazów cieplarnianych (GHG) w układzie „od źródła do koła" (Well to Wheel);

- brak ocen ekonomiczności produkcji DMF.

Jak widać, większość niedoskonałości wynika $\mathrm{z}$ niskiego stopnia zaawansowania badań nad dimetylofuranem, a więc przez wiele niewiadomych koniecznych do rozwiązania. Przewiduje się, że największymi barierami mogą okazać się: problemy ze zbiórką i transportem surowców do zakładu przemysłowego, postępowanie z powstającymi ściekami oraz wysokie koszty produkcji DMF.

\section{Surowce do wytwarzania DMF}

DMF jest paliwem wytwarzanym z cukrów prostych, takich jak fruktoza i glukoza. 冈e monosacharydy otrzymać można poprzez pocięcie łańcuchów polisacharydowych, najchętniej takich związków jak skrobia i celuloza. Cukry te pod dostatkiem występują w odpadowej biomasie.

Użyteczność biomasy jako materiału wsadowego do konwersji zależy od jej składu chemicznego i właściwości fizycznych. Biomasa zawiera zróżnicowane ilości celulozy, hemicelulozy i ligniny, które są jej głównymi składnikami.

Celuloza jest najpowszechniejszą formą węgla w biomasie, stanowiącą od 40 do $60 \%$ wagi biomasy, zależnie od źródła biomasy. Jest to kompleksowy linearny polimer cukrowy, utworzony z cząsteczek glukozy, w ilości od kilkunastu do kilkudziesięciu tysięcy jednostek, połączonych wiązaniami $\beta$-1,4-glikozydowymi. Jej krystaliczna struktura sprawia, że jest odporna na hydrolizę - reakcję chemiczną uwalniającą proste, fermentujące cukry z polisacharydu. Natomiast jej średnia wada cząsteczkowa to około 100.000 jednostek.

Hemiceluloza jest również jednym z głównych źródeł węgla w biomasie, na poziomie pomiędzy 20 a 40\% wagowych. Jest to polisacharydowy kompleks, który utworzony jest niemalże jedynie z różnych cukrów - najczęściej pięcio- lub sześcio-węglowych. W skład tej polisacharydowej mieszaniny wchodzą $\mathrm{m}$. in.: 
glukoza, mannoza, ksyloza, arabinoza, jak również kwas glikuronowy oraz jego pochodna - kwas metylogrukurunowy. Rozgałęzione struktury hemicelulozowe spotykane są w ścianach komórkowych roślin. Jest relatywnie łatwo zhydrolizować ją do cukrów prostych. Jej średnia waga cząsteczkowa to mniej niż 30.000 jednostek.

Lignina natomiast jest kompleksowym, rozgałęzionym polimerem aromatycznym, który zapewnia strukturalną integralność w roślinie. Stanowi ona 10 do $20 \%$ wagi biomasy. Jej struktury spotykane są w ścianach komórkowych roślin określonej biomasy, zwłaszcza drzewnej. Często, sąsiadując z włóknami celulozy tworzy kompleksy lignocelulozowe. Ligniny są określone jako grupa związków amorficznych, chemicznie powiązanych, o wysokiej wadze cząsteczkowej. Cząstki ligniny powinny zawierać trójwęglowe łańcuchy przyłączone do pierścieni sześciowęglowych, zwanych fenylopropanami. Lignina pozostaje jako odpadowy materiał, po tym jak cukry z biomasy są konwertowane do etanolu. Zawiera dużo energii i może być spalana dla produkcji ciepła i elektryczności w procesie biomasa do etanolu.

Celuloza jest generalnie największą frakcją w biomasie - po niej następują hemiceluloza, lignina, popiół itd.

Obecnie w Polsce biomasa wykorzystywana w przemyśle energetycznym pochodzi z dwóch gałęzi gospodarki: rolnictwa i leśnictwa. Branże te zbierają w Polsce ilość biomasy równoważną pod względem kalorycznym $150 \mathrm{mln}$ ton węgla. Przykładowo, wartości opałowe produktów biomasy na tle paliw konwencjonalnych wynoszą:

- słoma zó́łta - 14,3 MJ/kg,

- słoma szara - 15,2 MJ/kg,

- drewno odpadowe - $13 \mathrm{MJ} / \mathrm{kg}$,

- etanol - $25 \mathrm{MJ} / \mathrm{kg}$,

- węgiel kamienny - średnio około $25 \mathrm{MJ} / \mathrm{kg}$,

- gaz ziemny $-48 \mathrm{MJ} / \mathrm{kg}$.

\section{DMF w patentach}

DMF nie tylko może być stosowany jako biopaliwo, bądź biokomponent, ale również jako rozpuszczalnik organiczny. Już w połowie lat ' 40 dwudziestego wieku powstał patent na otrzymywanie acetonyloacetonu, w którym to procesie produktem pośrednim jest właśnie DMF. 区ytuł dokumentu to: „Proces otrzymywania 2,5-dimetylofuranu i acetonyloacetonu ${ }^{4}$ ". Jest to angielski patent, autorstwa Iana Morrisa Heilebrona oraz Ewarta Raya Herberta Jones'a, który zatwierdzony został dnia 28 stycznia 1946 roku w Londynie, pod numerem US2470070. Dwa

4 Inna nazwa: 2,5-heksadion; 
lata później ukazała się kompletna specyfikacja do tego patentu, zatytułowana: „Udoskonalenia odnoszące się do procesu otrzymywania 2,5-dimetylofuranu i acetonyloacetonu". Poniżej przybliżono ideę tego procesu.

Cały proces otrzymywania acetonyloacetonu przedstawiają poniższe reakcje:

1) $\mathrm{CH}_{3}-\mathrm{CH}=\mathrm{CH}-\mathrm{CH}(\mathrm{OH})-\mathrm{C} \equiv \stackrel{\text { (izomeryzacia) }}{\mathrm{CH}} \rightarrow \mathrm{CH}_{3}-\mathrm{CH}(\mathrm{OH})-\mathrm{CH}=\mathrm{CH}-\mathrm{C} \equiv \mathrm{CH}$,

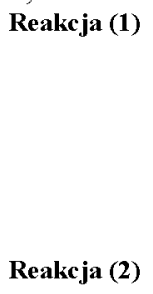

Reakcja (1)

Reakcja (2)

3)

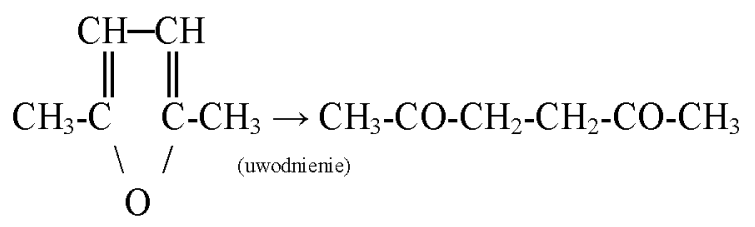

Reakcja (3)

Reakcja nr (1) ilustruje izomeryzację metanolu propenylo-etynylowego, reakcja nr (2) - przemianę heks-3-en-5-yn-2-olu w 2,5-dimetylofuran, a reakcja nr (3) - uwodnienie 2,5-dimetylofuranu do acetonyloacetonu. Należy przy tym dodać, że reakcje nr (2) i (3) mogą występować jednocześnie w mieszaninie reakcyjnej, prowadząc do otrzymania acetonyloacetonu bez wyizolowania produktu pośredniego reakcji - dimetylofuranu.

Zauważono, że heks-3-en-5-yn-2-ol przekształca się w acetonyloaceton poprzez proces hydratacji, a więc uwadnianie. DMF jest produktem pośrednim procesu otrzymywania acetonyloacetonu, a więc jest produktem pośrednim procesu uwadniania heks-3-en-5-yn-2-olu do acetonyloacetonu. Heks-3-en-5-yn-2-ol może być otrzymany z kolei drogą izomeryzacji metanolu propenylowo-etynylowego, poprzez poddanie go działaniu hydrolitycznemu.

Wynalazek jakim jest proces wytwarzania DMF, obejmuje poddawanie heks-3-en-5-yn-2-olu działaniu ciepła w obecności katalizatora rtęciowego. Obecność rozwodnionych kwasów, takich rozcieńczony kwas siarkowy, jest w tym procesie określana jako korzystna. Preferowana stężenie kwasu siarkowego zawiera się w wartościach $0,1 \%-10 \%$ wagowych.

Reakcja może być przeprowadzona w obecności obojętnego rozpuszczalnika. Rozpuszczalnik ten powinien być niższym alifatycznym alkoholem (mającym nie więcej niż 3 atomy węgla w cząsteczce), takim jak alkohol metylowy, podczas gdy 
uwodnione alkohole, takie jak uwodniony alkohol etylowy, również mogą być użyte.

2,5-dimetylofuran, produkowany w procesie otrzymywania acetonyloacetonu, może być wydzielony z mieszaniny reakcyjnej poprzez destylację parową - najlepiej tak szybko, jak tylko się uformuje. Przykładowo powolny strumień pary, wpuszczony do mieszaniny reakcyjnej może osiągnąć dwa cele: dostarczyć ciepło odpowiednie dla reakcji, oraz wydestylować dimetylofuran w chwili, gdy tylko powstanie.

Patent również obejmuje również uwodnienie heks-3-en-5-yn-2-olu do acetonyloacetonu w jednoetapowym procesie. Polega on na długotrwałym ogrzewaniu heksenynolu w rozcieńczonym, uwodnionym, średnim kwasie w obecności rtęciowego katalizatora. W wyniku poddaniu wysokiej temperaturze heksenynol przekształca się w 2,5-dimetylofuran, bądź bezpośrednio w acetonyloaceton. Oba związki mogą się tworzyć równocześnie w jednej mieszaninie reakcyjnej.

Do reakcji potrzebny jest katalizator w postaci soli rtęci, np. siarczanu rtęci. 凶aki katalizator można otrzymać działaniem odpowiedniego kwasu np. kwasu siarkowego na tlenek rtęci, bądź sól rtęciową, taką jak chlorek rtęci.

Cechą charakterystyczną reakcji jest przeprowadzanie jej w obecności katalizatora $\mathrm{HgO} \cdot \mathrm{BrF}_{3}$ (związek kompleksowy: tlenek rtęci i trifluorek bromu). Jednak w przypadku stosowania tego katalizatora reakcję należy przeprowadzić przy nieobecności wody. Można natomiast zastosować wolne od wody rozpuszczalniki, takie jak alkohol metylowy, który jest szczególnie odpowiedni w tym wypadku. 囚emperatura reakcji powinna być umiarkowana - zakres temperatur pomiędzy 50 a $100^{\circ} \mathrm{C}$ jest szczególnie satysfakcjonujący. Ponadto cały proces przeprowadzany jest w obojętnych warunkach, np. w azocie.

\section{Otrzymywanie DMF jako biopaliwa drugiej generacji}

Zarys ilustrujący proces konwersji węglowodanów w 2,5-dimetylofuran (DMF) jest przedstawiony na rys. 1 . 


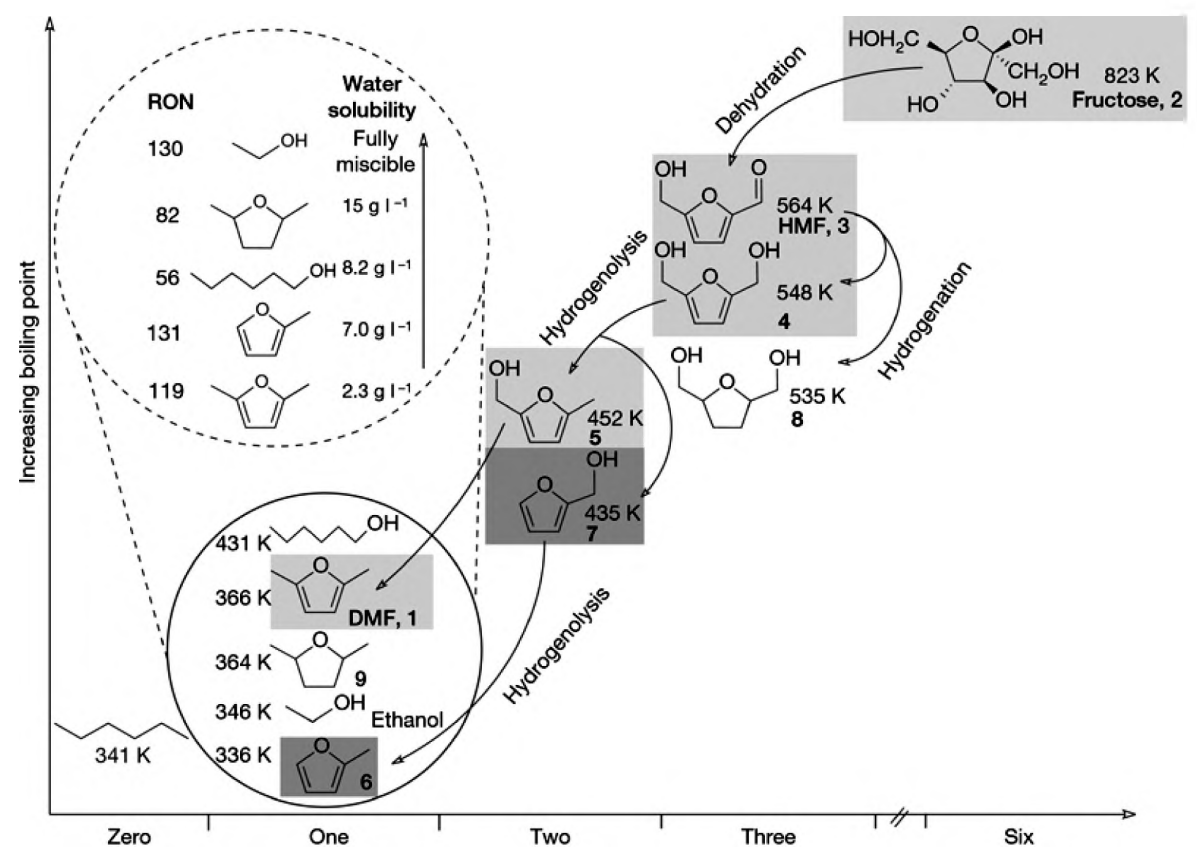

Rys. 1. Wykres zależności pomiędzy temperaturami wrzenia węglowodanów C6, formowanych przez usuwanie atomów tlenu $z$ heksoz, i ilościa zawartych atomów tlenu w kolejnych etapach produkcji DMF $z$ fruktozy

Wybiórcze usuwanie pięciu atomów tlenu z heksoz, takich jak fruktoza, do produkcji DMF nie tylko obniża punkt wrzenia do wartości odpowiedniej dla paliw płynnych. Osiąga ona również najniższą rozpuszczalność w wodzie i najwyższą liczbę oktanową (RON) z sześciowęglowych związków przy utrzymaniu wysokiej gęstości energetycznej. 囚en proces wybiórczego usuwania atomów tlenu może być spełniony w dwóch etapach:

1) Usunięcie trzech atomów tlenu poprzez dehydratację w rezultacie otrzymując 5-hydroksymetylofurfural (HMF);

2) Usunięcie dwóch kolejnych atomów tlenu poprzez proces hydrogenolizy, w której wyniku powstają pośrednie produkty 2,5-dihydroksymetylofuran oraz 2-metylo-5-hydroksymetylofurfural. 2-metylofuran otrzymany z alkoholu furfuralowego jest hydrogenolizowym ${ }^{5}$ produktem ubocznym, który również posiada znakomite właściwości paliwowe.

5 Hydrogenoliza - jest to katalityczna reakcja chemiczna, za pomocą której cząsteczka wodoru jest dodana do pojedynczego wiązania pomiędzy heteroatomem i węglem, efektywnie powodując zerwanie tego wiązania. Heteroatomem mogą być atomy różnych pierwiastków, ale zwykle jest to tlen, azot lub siarka; 
Schemat procesu otrzymywania DMF ilustruje rys. 2 .

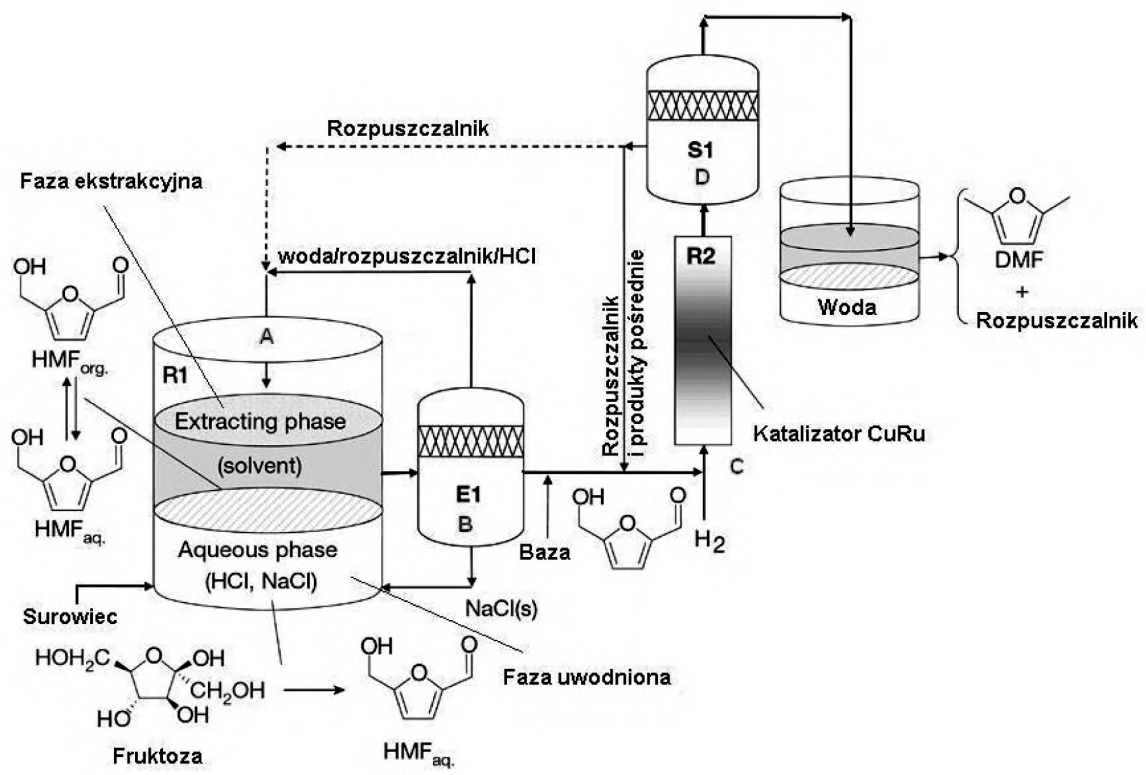

Rys. 2. Schemat konwersji fruktozy w DMF

Jego pierwszym etapem jest dehydratacja HMF katalizowana kwasem w dwufazowym reaktorze (oznaczonym na rys. 2 symbolem R1). Punkt wrzenia HMF jest zbyt wysoki względem wymagań paliwowych, bo wynosi $114-116^{\circ} \mathrm{C}$. Aby go obniżyć, HMF wyekstrahowany w organicznej fazie dwufazowego reaktora jest następnie przekształcany w DMF poprzez hydrogenolizę wiązania C-O za pomocą miedziano-rutenowego katalizatora $(\mathrm{CuRu} / \mathrm{C}$ ). Faza ekstrakcyjna (widoczna na rys. 2, opisana jako „Extracting phase”) przy użyciu organicznego rozpuszczalnika sprzyja ekstrakcji HMF z fazy wodnej. W następnych etapach jest obojętna i ułatwia oddzielenie finałowego produktu DMF.

Do zrealizowania procesu rozwinięto nowy katalityczny, wysoko wydajny system produkcji HMF ze stężonego roztworu cukrowego. Chociaż został opublikowany złożony, katalityczny system do produkcji HMF w rozpuszczalnikach zawierających komponenty o wysokim punkcie wrzenia, takich jak np. sulfotlenek dimetylowy, dla zduszenia reakcji ubocznych, to jednak śladowe ilości takich komponentów są szkodliwe dla jakości paliwa, a ich usunięcie wymaga intensywnych energetycznie procesów oczyszczania. HMF może być jednak również produkowany w wysokiej wydajności poprzez katalizowaną kwasem dehydratację fruktozy w dwufazowym reaktorze, przy użyciu rozpuszczalników o niskim punkcie wrzenia, które same są doskonałymi komponentami paliwowymi. 
Skutkiem tego jest wyeliminowanie potrzeby zastosowania drogich, niezależnych etapów dla otrzymania ostatecznej, płynnej mieszaniny paliwowej. Reaktywna faza wodna (widoczna na rys. 2 oznaczona symbolem R1 pod zacienioną fazą ekstrakcyjną) w dwufazowym reaktorze zawiera kwasowy katalizator i cukier, a faza ekstrakcyjna zawiera częściowo mieszalne rozpuszczalniki (np. butanol), które ciągle ekstrahują HMF z roztworu. Dodatek soli do fazy uwodnionej ulepsza rozdział HMF do ekstrakcyjnej fazy, co prowadzi do rosnącej wydajności HMF bez konieczności użycia rozpuszczalników o wysokim punkcie wrzenia.

Dwufazowy reaktor, używany przy okazji pierwszego etapu otrzymywania DMF jest widoczny na rys. 3. Przedstawia on także fotografię Yuriy’a Romana Leshkov'a, jednego z odkrywców tej metody otrzymywania DMF, trzymającego próbnik reaktora.

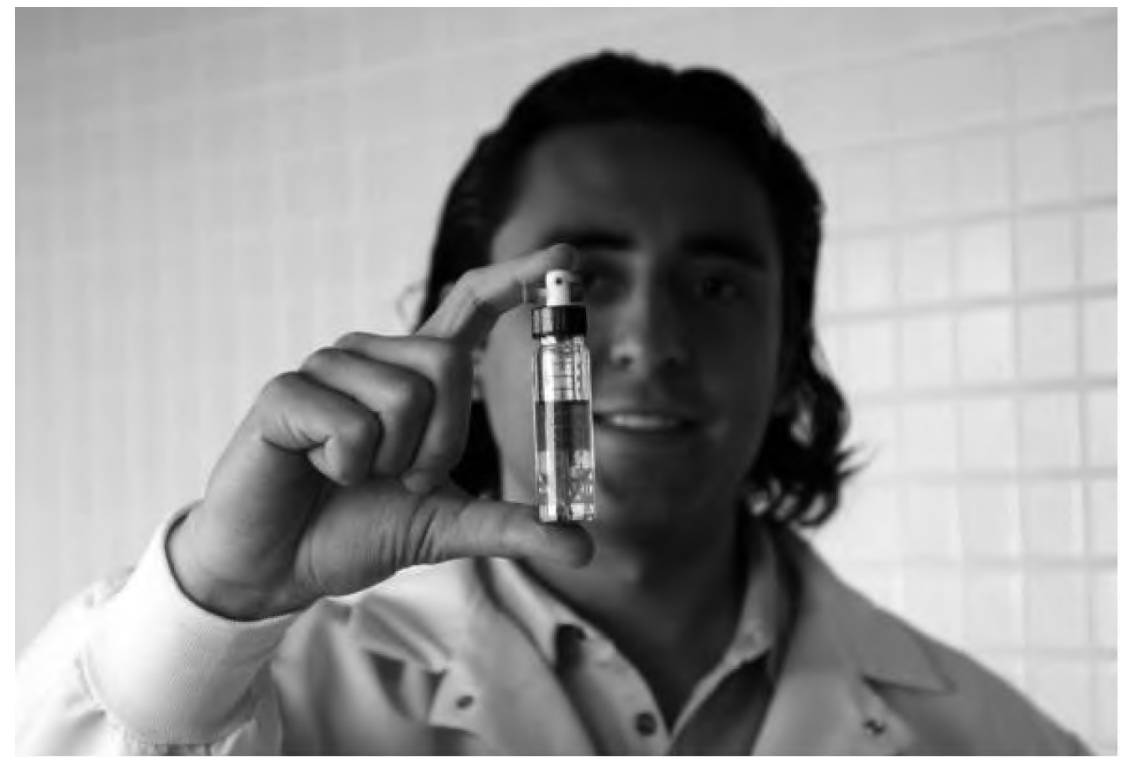

Rysunek 3. Zdjęcie Yuriyả Romána Leshkova trzymającego reaktor służący do przeprowadzenia pierwszego etapu w dwuetapowym procesie konwersji fruktozy w DMF.

Pojemność fazy organicznej do wyekstrahowania HMF z reaktywnej fazy wodnej, mierzona ekstrakcyjnym współczynnikiem $\mathrm{R}^{6}$, dokładnie oddziałuje na selektywność HMF, określoną przez mole wyprodukowanego HMF podzielone przez mole przereagowanej fruktozy.

Rezultaty badań pokazują, że selektywność HMF rośnie gdy współczynnik $\mathrm{R}$ rośnie, wskazując na to, że większa sprawność usuwania HMF z wodnej fazy

6 Współczynnik stężenia HMF w organicznej warstwie do stężenia w wodnej warstwie; 
zapobiega niepożądanym reakcjom ubocznym. Dodanie soli do reaktywnej fazy wodnej powoduje wzrost współczynnika $\mathrm{R}$ za pomocą efektu wysalania ${ }^{7}$, dzięki któremu elektrolity zmieniają międzycząsteczkowe wiążące oddziaływania pomiędzy płynnymi komponentami, obniżając wzajemną rozpuszczalność wodnej i organicznej fazy. Wartość współczynnika $\mathrm{R}$ dla określonego rozpuszczalnika ekstrahującego zależy nie tylko od powinowactwa rozpuszczalnika względem HMF, ale również od zdolności soli do rozdzielania obu faz. W aktualnych pracach dodanie $\mathrm{NaCl}$ do wodnej fazy powoduje największy wzrost współczynnika $\mathrm{R}, \mathrm{w}$ porównaniu do innych testowanych soli.

Tabela 2. Dehydratacja fruktozy przy użyciu innych soli niż $\mathrm{NaCl}$ (przy tych samym warunkach reakcji i przy początkowym wspótczynniku $R=3,2$ )

\begin{tabular}{|c|c|c|c|c|c|}
\hline $\begin{array}{c}\text { Aqueous } \\
\text { Phase } \\
\end{array}$ & Salt & $\begin{array}{c}\text { Organic } \\
\text { phase }\end{array}$ & $\begin{array}{c}\text { Conversion } \\
(\%)\end{array}$ & $\begin{array}{c}\text { Selectivity } \\
\text { HMF (\%) }\end{array}$ & $\mathbf{R}$ \\
\hline & $\mathrm{NaBr}$ & & 83 & 78 & 20 \\
\hline & $\mathrm{KCl}$ & & 89 & 82 & 26 \\
\hline & $\mathrm{KBr}$ & & 86 & 76 & 1.7 \\
\hline & $\mathrm{CaCl} 2$ & & 70 & 78 & 2.7 \\
\hline $30 w \%$ & $\mathrm{CsCl}$ & 2-butanol & 72 & 76 & 2.0 \\
\hline fructose & $\mathrm{MgCl} 2$ & & 78 & 77 & 28 \\
\hline & NaNO3 & & & & \\
\hline & $\mathrm{Na} 2 \mathrm{SO} 4$ & & \multirow{2}{*}{\multicolumn{3}{|c|}{$\begin{array}{c}\text { LOW REACTIVITY AND SOLID } \\
\text { FORMATION }\end{array}$}} \\
\hline & $\mathrm{Na} 2 \mathrm{HPO} 4$ & & & & \\
\hline
\end{tabular}

Jak widać z tabeli 2 użycie innych soli niż $\mathrm{NaCl}$ powoduje spadek wielkości współczynnika R, a co za tym idzie również spadek selektywności.

W porównaniu do eksperymentów bez soli, 30\%-owy roztwór fruktozy nasycony $\mathrm{NaCl}\left(35 \% \mathrm{NaCl}\right.$ na $100 \mathrm{~g} \mathrm{H}_{2} \mathrm{O}$ ) przy użyciu 2-butanolu jako ekstrahującego rozpuszczalnika (ze wstępnym wspólczynnikiem organicznej i wodnej fazy wielkości $\mathrm{V}_{\text {org. }} / \mathrm{V}_{\mathrm{aq}}=1,6$ ) powoduje wzrost współczynnika $\mathrm{R}$ z 1,6 do 3,3 prowadząc do ulepszenia selektywności HMF z 66\% do 79\% (tabela 3, punkt 1 i 6).

\footnotetext{
7 Strącanie substancji $\mathrm{z}$ roztworu lub zmniejszenie rozpuszczalności gazów w cieczy przez dodanie elektrolitów (nie reagujących $z$ daną substancją), których zdysocjowane jony są silnie solwatowane przez cząsteczki rozpuszczalnika;

8 Procent wagowy;
} 
Tabela 3. Wyniki dehydratacji dla 30\%-owego roztworu fruktozy

\begin{tabular}{|c|c|c|c|c|c|c|c|c|c|}
\hline Run & $\begin{array}{l}\text { Salt } \\
(\%)\end{array}$ & Organic phase & $\begin{array}{c}\text { Conversion } \\
(\%)\end{array}$ & $\begin{array}{c}\text { Selectivity } \\
(\%)\end{array}$ & $\begin{array}{c}{[H M F]_{a q \cdot}(g} \\
\left.\Gamma^{-1}\right)\end{array}$ & $\begin{array}{c}{[H M F]_{\text {org. }}(g} \\
\left.\Gamma^{-1}\right)\end{array}$ & $\boldsymbol{R}$ & $\begin{array}{c}\text { [Salt] }]_{\text {org. }}(\mathrm{g} \\
\left.\mathrm{I}^{-1}\right)\end{array}$ & $\begin{array}{c}{\left[\mathrm{H}_{2} \mathrm{O}\right]_{\text {org }}} \\
\quad(w t \%)\end{array}$ \\
\hline 1 & $0 *$ & 2-butanol & 58 & 66 & 28.6 & 46.0 & 1.6 & 0.0 & 31.4 \\
\hline 2 & 5 & 2-butanol & 65 & 77 & 16.8 & 34.1 & 2.0 & 0.9 & 16.4 \\
\hline 3 & 15 & 2-butanol & 65 & 85 & 12.7 & 34.4 & 2.7 & 1.1 & 9.6 \\
\hline 4 & 25 & 2-butanol & 75 & 88 & 11.6 & 37.9 & 3.3 & 1.2 & 6.8 \\
\hline 5 & 35 & 2-butanol & 74 & $89 \underline{\xi}$ & 10.6 & 38.1 & 3.6 & 1.6 & 6.5 \\
\hline 6 & $35^{*}$ & 2-butanol & 71 & 79 & 18.0 & 60.0 & 3.3 & 1.6 & 7.4 \\
\hline 7 & 0 & 1-butanol & 52 & 71 & 15.1 & 26.0 & 1.7 & 0.0 & 23.1 \\
\hline 8 & 35 & 1-butanol & 85 & $82^{\S}$ & 13.2 & 39.2 & 3.0 & 1.6 & 6.1 \\
\hline 9 & $35^{ \pm}$ & 1-butanol & 80 & 83 & 12.0 & 39.0 & 3.3 & 1.6 & 6.1 \\
\hline 10 & $35^{\dagger}$ & 1-butanol & 88 & 82 & 12.9 & 43.1 & 3.3 & 1.6 & 6.1 \\
\hline 11 & $35^{ \pm}$ & 1-butanol & 77 & 84 & 12.4 & 37.8 & 3.0 & 1.6 & 6.1 \\
\hline 12 & $35^{\dagger}$ & 1-butanol & 64 & 84 & 10.2 & 32.4 & 3.2 & 1.6 & 6.1 \\
\hline 13 & 0 & 1-hexanol & 50 & 64 & 21.1 & 18.4 & 0.9 & 0.0 & 7.9 \\
\hline 14 & 35 & 1-hexanol & 78 & 72 & 19.5 & 29.9 & 1.5 & 0.9 & 2.2 \\
\hline 15 & 0 & MIBK & 50 & 71 & 20.0 & 21.8 & 1.1 & 0.0 & 0.9 \\
\hline 16 & 35 & MIBK & 72 & 77 & 18.3 & 29.3 & 1.6 & 0.2 & 0.0 \\
\hline 17 & 0 & $\begin{array}{l}\text { Toluene:2- } \\
\text { butanol|| }\end{array}$ & 64 & 78 & 27.7 & 31.7 & 1.2 & 0 & 6.7 \\
\hline 18 & 35 & $\begin{array}{c}\text { Toluene:2- } \\
\text { butanol|| }\end{array}$ & 74 & 88 & 13.8 & 37.4 & 2.7 & 0.8 & 1.9 \\
\hline 19 & 0 & None & 44 & 55 & 53.5 & 0.0 & 0.0 & 0.0 & - \\
\hline 20 & 35 & None & 59 & 57 & 70.8 & 0.0 & 0.0 & 35.0 & - \\
\hline 21 & $5^{\ddagger}$ & 2-butanol & 30 & 36 & 1.2 & 2.3 & 1.9 & 0.9 & 16.4 \\
\hline 22 & $35^{\ddagger}$ & 2-butanol & 56 & 48 & 1.1 & 3.9 & 3.6 & 1.6 & 6.5 \\
\hline
\end{tabular}

Szczególnie obecność NaCl przynosi dodatkowe korzyści pozwalając na użycie wyższych wartości $\mathrm{V}_{\text {org. }} / \mathrm{V}_{\text {aq. }}$, dlatego prowadzi do wyższej selektywności HMF, utrzymując warunki dwufazowej reakcji. Zwłaszcza, gdy współczynnik $\mathrm{V}_{\text {org. }} / \mathrm{V}_{\text {aq. }}$ jest podwojony, system 2-butanolu bez soli staje się jednofazowy, podczas gdy system nasycony $\mathrm{NaCl}$ pozostaje dwufazowy, z $\mathrm{R}=3,6$ i selektywnością $\mathrm{HMF}$ równą 89\% (tabela 3, punkt 5).

Podstawową rolą $\mathrm{NaCl}$ jest zmiana własności rozpuszczalnika, bo w przeciwnym razie zachowuje obojętność. Szczególnie dehydratacja fruktozy w obecności $\mathrm{NaCl}$, ale bez obecności ekstrahującego rozpuszczalnika, prowadzi do tej samej selektywności HMF jak przy braku $\mathrm{NaCl}$ (tabela 3, punkty 19 i 20).

Chociaż różne rozpuszczalniki ekstrahujące mogą generować wysoką selektywność HMF, to użycie 1-butanolu jako rozpuszczalnika jest korzystne dla zastosowań biomasy. Rozpuszczalniki takie jak 2-butanol są otrzymywane z ropopochodnych produktów (poprzez hydrolizę 2-butenu), podczas gdy 1-butanol może być produkowany poprzez fermentację węglowodanów pochodzących z biomasy. Dodatkową zaletą 1-butanolu jest to, że jest obojętny w etapie hydrogenolizy. Reakcja dehydratacji z użyciem 1-butanolu i wodnej fazy nasyconej $\mathrm{NaCl}$ pokazuje wartość współczynnika R na 3,0 i selektywność HMF na 82\% (tabela 3, punkt 8). Podczas używania 1-butanolu obserwujemy, że selektywność HMF jest niezależna od obecności kwasu w eksperymencie, przy stężeniu $\mathrm{HCl}$ od 0,01 do $0,25 \mathrm{~mol} / \mathrm{l}$ (tabela 3 , punkty $8-12$ ). 
Ekstrahujący rozpuszczalnik zawierający HMF następnie zostaje poddany etapowi oczyszczania. Analogicznie do eksperymentu w punkcie $12 \mathrm{w}$ tabeli 3, strumień wchodzący do parownicy zawiera $260 \mathrm{mmol} \mathrm{l}^{-1} \mathrm{HMF}$ (mierzony wysoko sprawną chromatografią cieczową, HPLC), $2800 \mathrm{mmol} \mathrm{l}^{-1}$ wody, $26 \mathrm{mmol} \mathrm{l}^{-1} \mathrm{NaCl}$ (mierzony HPLC), 3,6 $\mathrm{mmol} \mathrm{l}^{-1} \mathrm{HCl}$ (mierzoną przez miareczkowanie z NaOH) i 1,1 $\mathrm{mmol} \mathrm{l}^{-1} 1$-chlorobutanu (mierzony przez chromatografię gazową).

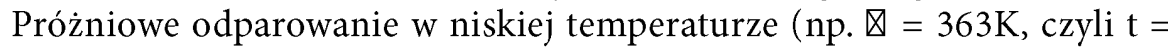
$90^{\circ} \mathrm{C}$ ) może być użyte do rozdzielenia lotnych zanieczyszczeń od komponentów z względnie niższą lotnością, jak HMF i 1-butnol. Ponadto ponieważ rozpuszczalność $\mathrm{NaCl}$ w bezwodnych rozpuszczalnikach organicznych jest niższa niż w wodzie, usuwanie wody powoduje, że sól gwałtownie opuszcza roztwór. Odparowanie $25 \%$ całkowitej masy wchodzącego strumienia obniża poziom zanieczyszczenia do $360 \mathrm{mmol} \mathrm{l}^{-1}$ wody, 1,6 $\mathrm{mmol} \mathrm{l}^{-1} \mathrm{NaCl}, 1,5 \mathrm{mmol} \mathrm{l}^{-1} \mathrm{HCl}, 0,2$ $\mathrm{mmol} \mathrm{l}^{-1} 1$-chlorobutanu. Poziomy 1-chlorobutanu są obniżone poniżej wykrytych ograniczeń $\left(<0,1 \mathrm{mmol} \mathrm{l}^{-1}\right)$, przez neutralizację przy użyciu $\mathrm{NaOH}$ oczyszczonego strumienia opuszczającego parownicę. Dlatego woda, $\mathrm{NaCl}$, frakcje 1-butanolu parują i $58 \% \mathrm{HCl}$ są odzyskane i przetworzone z powrotem do dwufazowego reaktora, podczas gdy oczyszczony płynny strumień zawierający HMF i 1-butanol jest przesyłany do dalszego przetwarzania.

Tabela 4. Hydrogenoliza fazy plynnej we wsadowym reaktorze

\begin{tabular}{|c|c|c|c|c|c|c|c|c|c|c|}
\hline \multirow[b]{2}{*}{ Run } & \multirow[b]{2}{*}{ Catalyst } & \multirow{2}{*}{$\begin{array}{c}\text { Pre- } \\
\text { contacted } \\
\text { with } \mathrm{H}_{2} \mathrm{O} \\
\text { and } \mathrm{NaCl} \\
\end{array}$} & \multirow[b]{2}{*}{ Solvent } & \multirow[b]{2}{*}{$\begin{array}{c}\text { Conversion } \\
\text { (\%) }\end{array}$} & \multicolumn{5}{|c|}{ Selectivity } & \multirow[b]{2}{*}{$\begin{array}{c}\text { Carbon } \\
\text { Out } / \text { In } \\
(\%)\end{array}$} \\
\hline & & & & & $\begin{array}{l}\text { DMF } \\
(\%)\end{array}$ & $\begin{array}{r}5 \\
(\%)\end{array}$ & $\begin{array}{c}6 \\
(\%)\end{array}$ & $\begin{array}{c}7 \\
(\%)\end{array}$ & $\begin{array}{c}8 \\
(\%)\end{array}$ & \\
\hline 1 & $\begin{array}{c}3: 1 \\
\text { CuRuC }\end{array}$ & Yes & 1-butanol & 100 & 41.0 & 8.0 & 5.9 & 22 & 3.3 & 80 \\
\hline $1^{\dagger}$ & $\begin{array}{c}3: 1 \\
\text { CuRuC }\end{array}$ & $\begin{array}{l}\text { Yes, and } \\
\text { purified }\end{array}$ & 1-butanol & 100 & 61.0 & 9.4 & 3.6 & 11 & 1.8 & 86 \\
\hline 2 & $\begin{array}{c}3: 1 \\
\text { CuRuC }\end{array}$ & No & 1-butanol & 100 & 71.0 & 5.1 & 4.3 & 7.2 & 1.8 & 89 \\
\hline 3 & $\begin{array}{c}\text { CuCrO } \\
\text { (Barium } \\
\text { promoted) }\end{array}$ & Yes & 1-butanol & 18 & 0.0 & 0.0 & 0.0 & 0.0 & 0.0 & 82 \\
\hline $3^{\dagger}$ & $\begin{array}{c}\text { CuCrO } \\
\text { (Barium } \\
\text { promoted) }\end{array}$ & $\begin{array}{l}\text { Yes, and } \\
\text { purified }\end{array}$ & 1-butanol & 94 & 6.0 & 12.0 & 2.1 & 2.3 & 0.4 & 87 \\
\hline 4 & $\begin{array}{c}\text { CuCrO } \\
\text { (Barium } \\
\text { promoted) }\end{array}$ & No & 1-butanol & 100 & 61.0 & 29.0 & 0.0 & 0.0 & 2.8 & 92 \\
\hline
\end{tabular}

Następnie HMF jest przekształcany w DMF przy pomocy miedzianego katalizatora, widocznego na rys. 2 oznaczonego symbolem R2. Poprzednie badania 
pokazały, że chromian VI miedzi $\left(\mathrm{CuCrO}_{4}\right)$ selektywnie przekształca furfural w alkohol furfurylowy i 2-metylofuran bez nadmiernego uwodornienia pierścienia furanowego lub też nadmiernego pierścieniowego rozpadu produktów. Odpowiednio $\mathrm{CuCrO}_{4}$ powinien być efektywnym katalizatorem dla hydrogenolizy HMF do DMF. Jednak żadne badania tej reakcji nie zostały opublikowane. Grupa eksperymentów na fazie płynnej hydrogenolizy $\mathrm{HMF}$ z użyciem $\mathrm{CuCrO}_{4}$ pokazuje $61 \%$ zysk (zdefiniowany jako produkt selektywności i przekształceń) dla DMF (tabela 4, punkt 4) i 29\% zysk dla 2-metylo-5-hydroksymetylofuranu. Znacząco, jednakże śledzone poziomy jonów chlorkowych w rozpuszczalniku (wprowadzone podczas etapu dehydratacyjnego i niekompletnego usunięcia podczas etapu parowania) deaktywują katalizator $\mathrm{CuCrO}_{4}$ znacząco. $\mathrm{Na}$ przykład kiedy ten katalizator jest użyty w roztworze 1-butanolu zawierającym 1,6 mmol ${ }^{-1} \mathrm{NaCl}$, tylko 6\% zysk DMF jest otrzymany (tabela 4, punkt $3^{\dagger}$ ). Literatura dotycząca deaktywacji katalizatora miedzianego przez znikome ilości struktur chlorkowych wskazują, że podstawowym sposobem deaktywacji jest, spowodowane przez chlorek, spiekanie miedzi.

Celem zmniejszenia zatrucia miedzianego katalizatora, został wprowadzony chlorko odporny, węglo wspierający katalizator miedziano-rutenowy $(\mathrm{CuRu} / \mathrm{C})$. Powodem użycia tego katalizatora było to, że najpierw zaobserwowano, iż rutenowy katalizator, wspierający węgiel, był odporny na deaktywację w obecności jonów chlorkowych. Jednakże ten katalizator przekształca HMF najpierw w 2,5-dihydroksymetylotetrahydrofuran. Ponieważ miedź i ruten nie mieszają się nawzajem, i miedź ma niższą energię powierzchniową niż ruten, ich mieszanina stwarza dwufazowy system, w którym miedziowa faza powleka powierzchnię rutenowej fazy. Odpowiednio, przewiduje się, że katalizator $\mathrm{CuRu} / \mathrm{C}$ połączy miedziowe zachowanie hydrogenolizy z rutenową odpornością na chlorki.

Przy okazji procesu hydrogenolizy z fazy płynnej używając katalizatora $\mathrm{CuRu} / \mathrm{C}$ w stosunku 3:1 (współczynnik atomowy) zysk wynosi 71\% DMF, 4\% 2-metylofuranu i $12 \%$ produktów pośrednich (tabela 4, punkt 2). இen sam katalizator użyty z oczyszczonym roztworem 1-butanolu zawierającym $1,6 \mathrm{mmol} \mathrm{l}^{-1}$ $\mathrm{NaCl}$ generuje zysk $61 \%$ DMF, 4\% 2-metylofuranu i $20 \%$ produktów pośrednich (tabela 4 , punkt $1^{\dagger}$ ). Dlatego chociaż $\mathrm{CuRu} / \mathrm{C}$ jest obciążony w pewnym stopniu przez obecność struktur chlorkowych, jego działanie jest wybitnie lepsze niż działanie katalizatora $\mathrm{CuCrO}_{4}$.

Poniżej przedstawiony jest schematyczny rysunek reaktora przepływowego, wykorzystanego w fazie parowej (rys. 4). 


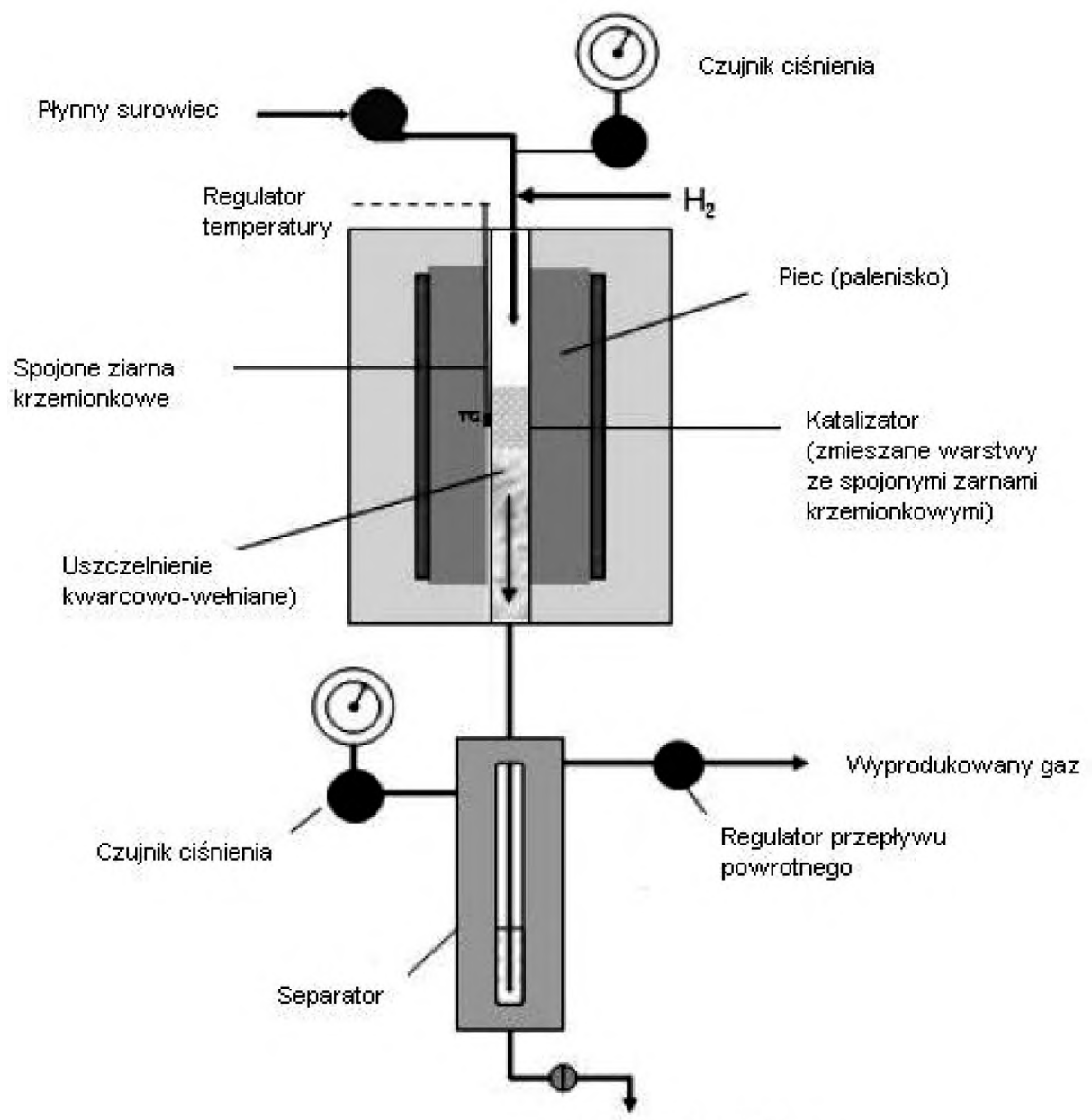

Prynny odptyw (sciek)

Rys. 4. Schematyczne zilustrowanie reaktora przeptywowego fazy parowej

$\mathrm{W}$ innym wypadku, ponieważ $\mathrm{NaCl}$ nie paruje, faza parowa procesu hydrogenolizy jest przygotowana przy użyciu reaktora przepływowego dla wyeliminowania oddziaływania jonów chlorkowych na $\mathrm{CuRu} / \mathrm{C}$. Faza parowa hydrogenolizy przy wykorzystaniu stosunku 3:2 katalizatora $\mathrm{CuRu} / \mathrm{C}$ pokazuje $76-79 \% \mathrm{zy}$ sku DMF i około 5\% produktów pośrednich dla 1,5\% i 10\% wagowych surowca HMF (tabela 5, punkty 6 i 8-12). Niechlorowane węglowodory zostały wykryte po reakcji. Dlatego, chociaż proces fazy parowej wymaga parowania surowców, to jednak wynikają z tego procesu wielorakie korzyści. Po pierwsze, w porów- 
naniu do fazy płynnej, nie generowane są żadne produkty uboczne i powstaje mniej produktów pośrednich. Po drugie, proces może przebiegać dwojako: zarówno w rozcieńczonym jak i stężonym roztworze HMF. Po trzecie, ponieważ te same wyniki zostały otrzymane kiedy używano 1-butanolu lub 1-heksanolu, inne także mogą być użyte bez zmiany selektywności (tabela 5). I po ostatnie, mimo że katalizator wolno deaktywuje po przetworzeniu ilości HMF odpowiadającej niemalże dwukrotnej masie katalizatora (1,7 razy masa katalizatora), może być zregenerowany w pełni poprzez płynny wodór w reakcyjnej temperaturze.

Tabela 5. Hydrogenoliza fazy parowej w reaktorze przeplywowym [90].

\begin{tabular}{|c|c|c|c|c|c|c|c|c|}
\hline \multirow[b]{2}{*}{ Run } & \multirow[b]{2}{*}{ Catalyst } & \multirow[b]{2}{*}{ Solvent } & \multirow{2}{*}{ 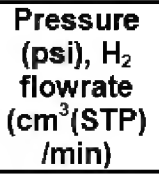 } & \multicolumn{5}{|c|}{ Yield } \\
\hline & & & & $\begin{array}{c}\mathrm{HMF} \\
(w t \%)\end{array}$ & $\begin{array}{c}\text { DMF } \\
(\%)\end{array}$ & $\begin{array}{c}5 \\
(\%)\end{array}$ & $\begin{array}{c}6 \\
(\%)\end{array}$ & $\begin{array}{c}\text { Carbon } \\
\text { Out / In } \\
(\%)\end{array}$ \\
\hline 5 & $\mathrm{CuCrO}_{4}$ & 1-butanol & 250,19 & 1.5 & 52.0 & 0.0 & 0.0 & 52 \\
\hline 6 & $3: 2$ CuRu/C & 1-butanol & 250,19 & 1.5 & 77.0 & 0.0 & 0.0 & 77 \\
\hline 7 & $3: 2$ CuRu/C & 1-butanol & 50,19 & 1.5 & 62.0 & 0.0 & 4.0 & 66 \\
\hline 8 & $3: 2$ CuRu/C & 1-hexanol & 100,42 & 1.5 & 78.0 & 0.0 & 0.0 & 78 \\
\hline 9 & $3: 2 \mathrm{CuRu} / \mathrm{C}$ & 1-hexanol & 100,42 & 10.0 & 78.0 & 4.0 & 2.0 & 84 \\
\hline 10 & 32 CuRu/C & 1-butanol & 250,19 & 10.0 & 76.0 & 0.0 & 2.0 & 78 \\
\hline 11 & $3: 2 \mathrm{CuRu} / \mathrm{C}$ & 1-butanol & 250,19 & 10.0 & 79.0 & 6.0 & 1.0 & 86 \\
\hline 12 & $3: 2$ CuRu/C & 1-butanol & 250,19 & 10.0 & 76.0 & 5.0 & 1.0 & 82 \\
\hline 13 & 3:1 CuRu/C & 1-butanol & 250,19 & 1.5 & 72.0 & 0.0 & 0.0 & 72 \\
\hline \multirow[t]{2}{*}{$14^{\dagger}$} & $3: 1 \mathrm{CuRu} / \mathrm{C}$ & 1-butanol & 250,19 & 1.7 & 72.0 & 0.0 & 0.0 & 72 \\
\hline & & \multicolumn{7}{|c|}{ Dimethylfuran wt (\%) } \\
\hline 15 & 32 CuRu/C & 1-butanol & 250,19 & 1.1 & 93.0 & 0.0 & 0.0 & 93 \\
\hline
\end{tabular}

DMF może być opcjonalnie uwodorniony do 2,5-dimetylotetrahydrofuranu poprzez katalizator rutenowy. 2,5-dimetylotetrahydrofuran zawiera wyższy współczynnik wodoru do węgla niż DMF, co się przekłada na wyższą zawartość energetyczną. Ponadto, 2,5-dimetylotetrahydrofuran może dostarczać dodatkową stabilność w długookresowym magazynowaniu, ponieważ zawiera w pełni uwodorniony pierścień furanowy. \oksykologiczne właściwości DMF i 2,5-dimetylotetrahydrofuranu nie zostały gruntownie zbadane. Dostępne informacje sugerują, że DMF nie jest bardziej toksyczny niż aktualne paliwowe komponenty. Jednakże zanim ten furanowy komponent zostanie zatwierdzony do komercyjnego użycia, będą musiały być wykonane długoterminowe badania.

Ostatni etap dotyczy oddzielenia DMF od rozpuszczalnika i produktów pośrednich. Na rysunku 2 etap ten jest widoczny w prawym górnym rogu. Bardziej lotne komponenty (to jest DMF, 2-metylofuran i woda) mogą być oddzielone od rozpuszczalnika i produktów pośrednich. Końcowy strumień może być od- 
zyskany i zawrócony do reaktora hydrogenolizy. Przy skraplaniu, hydrofobowe produkty DMF i 2-metylofuran oddzielają się samoistnie od wody. Zależnie od wymagań ostatecznego składu paliwa, proces destylacyjny może być użyty do bardziej precyzyjnej kontroli dystrybucji komponentów i również odzyskania frakcji z rozpuszczalnika do reaktora dehydratacyjnego. Odnotowano, że wymagania energetyczne do odparowania strumienia zawierającego DMF i 1-butanol, prowadzącego do oddzielenia produktu, jest jak jeden do trzech w stosunku do energii wymaganej do odparowania wodnego roztworu etanolu produkowanego poprzez fermentację do zastosowań paliwowych.

Wydajność produkcji DMF z biomasy na wielką skalę będzie ulepszona, jeśli wykorzystane zostaną łatwo dostępne surowce, takie jak glukoza. Jednakże produkcja HMF z glukozy przynosi umiarkowane zyski. Konwersja $\mathrm{z}$ fruktozy jest bardziej selektywna, a więc fruktoza zdaje się być bardziej odpowiednim substratem. Istnieją już wydajne procesy do wysoko-poziomowego produkowania fruktozy z glukozy, takie jak katalizowana enzymami izomeryzacja połączona z rozdzieleniem $\mathrm{SMB}^{9}$ (simulated moving-bed). Chociaż wyzwania pozostają dla zastosowań komercyjnych, te badania otwierają nową ścieżkę dla produkcji DMF jako płynnego paliwa transportowego otrzymywanego $z$ biomasy.

\section{Możliwości zastosowania DMF w silnikach o zapłonie iskrowym}

Dotychczasowe badania nad właściwościami DMF ukazują ten związek jako bardzo dobre biopaliwo bądź biokomponent do silników o zapłonie iskrowym (ZI).

Paliwo przeznaczone do zasilania silników o zapłonie iskrowym powinno mieć takie właściwości, aby:

- zapewnić prawidłowe tworzenie mieszanki paliwowo-powietrznej,

- zapewnić prawidłowe i efektywne (bezstukowe) spalanie,

- nie oddziaływać negatywnie ani bezpośrednio, ani pośrednio na środowisko naturalne,

- zachować trwałość w procesach magazynowania, dystrybucji i w układzie zasilania pojazdu.

We wcześniejszych okresach rozwoju motoryzacji konstrukcja silników ZI oraz wymagania dla zasilających je paliw miały na celu osiągnięcie możliwie największej sprawności, a więc największej mocy z jednostki pojemności skokowej. Obecnie natomiast wymagania te ukierunkowane są przede wszystkim na:

- ochronę środowiska - minimalną emisję toksycznych spalin i ditlenku węgla;

- minimalizację zużycia paliwa - zmniejszenie kosztów eksploatacji silnika i emisji $\mathrm{CO}_{2}$,

$9 \quad$ SMB (simulated moving-bed) - w chromatografii technika ta jest wariantem chromatografii płynów o wysokiej sprawności. Jest stosowana do oddzielenia cząsteczek i/lub związków chemicznych, które trudno byłoby rozdzielić w inny sposób, bądź byłoby to w ogóle nie możliwe; 
a dopiero potem na doskonalenie osiągów silnika. Determinuje to również wymagania odnośnie paliw do zasilania silników ZI.

Aktualne wymagania jakościowe dla benzyn silnikowych zostały przedstawione w tabeli 6.

Tabela 6. Wymagania jakościowe dla benzyn silnikowych obowiqzujące w Polsce od $01.01 .2005 r$.

\begin{tabular}{|c|c|c|c|}
\hline \multirow{2}{*}{ PARAME冈R } & \multirow{2}{*}{$\begin{array}{l}\text { JEDNOS囚KA } \\
\text { MIARY }\end{array}$} & \multicolumn{2}{|c|}{ ZAKRES WAR®OŚCI } \\
\hline & & minimum & maksimum \\
\hline $\begin{array}{l}\text { Liczba oktanowa badawcza, LOB: } \\
\text { - benzyna bezołowiowa } 95 \\
\text { - benzyna bezołowiowa } 98 \\
\end{array}$ & & $\begin{array}{l}95,0 \\
98,0 \\
\end{array}$ & $\begin{array}{l}- \\
- \\
\end{array}$ \\
\hline $\begin{array}{l}\text { Liczba oktanowa motorowa, LOM: } \\
\text { - benzyna bezołowiowa } 95 \\
\text { - benzyna bezołowiowa } 98 \\
\end{array}$ & & $\begin{array}{l}85,0 \\
88,0 \\
\end{array}$ & - \\
\hline Prężność par10 & $\mathrm{kPa}$ & - & 60,0 \\
\hline $\begin{array}{l}\text { Skład frakcyjny: } \\
\text { - do temperatury } 100^{\circ} \mathrm{C} \text { destyluje } \\
\text { - do temperatury } 150^{\circ} \mathrm{C} \text { destyluje (E150) }\end{array}$ & $\begin{array}{l}\% \text { obj. } \\
\% \text { obj. }\end{array}$ & $\begin{array}{l}46,0 \\
75,0 \\
\end{array}$ & - \\
\hline $\begin{array}{l}\text { Zawartość węglowodorów: } \\
\text { - olefinowych } \\
\text { - aromatycznych }\end{array}$ & $\begin{array}{l}\% \text { obj. } \\
\% \text { obj. }\end{array}$ & - & $\begin{array}{l}18,0 \\
35,0\end{array}$ \\
\hline Zawartość benzenu & $\%$ obj. & - & 1,0 \\
\hline Zawartość tlenu & $\%$ masy & - & 2,7 \\
\hline $\begin{array}{l}\text { Zawartość organicznych związków tleno- } \\
\text { wych: } \\
\text { - metanol (wymagany stabilizator) } \\
\text { - etanol (może być konieczne dodatnie } \\
\text { stabilizatora) } \\
\text { - alkohol izopropylowy } \\
\text { - alkohol tertbutylowy } \\
\text { - alkohol izobutylowy } \\
\text { - etery ( } 5 \text { lub więcej atomami węgla } \\
\text { w cząsteczce) }\end{array}$ & $\begin{array}{l}\% \text { obj. } \\
\% \text { obj. } \\
\% \text { obj. } \\
\% \text { obj. } \\
\% \text { obj. } \\
\% \text { obj. }\end{array}$ & $\begin{array}{l}- \\
- \\
- \\
- \\
- \\
-\end{array}$ & $\begin{array}{c}3 \\
\\
5 \\
10 \\
7 \\
10 \\
\\
15 \\
\end{array}$ \\
\hline \multirow{3}{*}{$\begin{array}{l}\text { Inne związki organiczne zawierające tlen } \\
\text { Zawartość siarki }\end{array}$} & \multirow{3}{*}{$\begin{array}{l}\% \text { obj. } \\
\mathrm{mg} / \mathrm{kg}\end{array}$} & - & 10 \\
\hline & & - & 50 \\
\hline & & - & 1011 \\
\hline Zawartość ołowiu & $\mathrm{mg} / \mathrm{l}$ & - & 0,005 \\
\hline
\end{tabular}

10 W okresie letnim (od 1.05 do 30.09).

${ }_{11}$ Od $1.01 .2005 \mathrm{r}$. benzyny silnikowe o maksymalnej zawartości siarki $10 \mathrm{mg} / \mathrm{kg}$ powinna być dostępna na calym terytorium RP, a od 1.01 .2009 r. może być sprzedawana tylko benzyna silnikowa o maksymalnej zawartości siarki $10 \mathrm{mg} / \mathrm{kg}$. 
Jednym z ważniejszych parametrów określających właściwości paliw do silników ZI jest ich lotność, która musi być ściśle określona ze względu na:

- uzyskanie optymalnych warunków pracy silnika i jego osiągów;

- minimalizację toksyczności spalin;

- prawidłowe funkcjonowanie układu zasilania silnika;

- minimalizację strat i przenikania par benzyny do otoczenia;

- temperaturę otoczenia oraz warunki klimatyczne przy eksploatacji silnika.

Lotność między innymi determinuje łatwość parowania paliwa w układzie zasilania oraz przenikanie do otoczenia w cyklu od magazynowania po użytkowanie w pojazdach. Właściwość ta również ma wpływ na proces tworzenia oraz spalania mieszanki paliwowo-powietrznej, uruchamianie zimnego i ciepłego silnika oraz skład spalin.

Ze względu na ochronę środowiska dąży się do użytkowania benzyn silnikowych o możliwie małej lotności, ale przy zapewnieniu optymalnych warunków spalania oraz minimalizacji zużycia paliwa i toksyczności spalin. Ponadto w okresie zimowym należy stosować benzyny o wyższej lotności, natomiast te o niższej lotności - w okresie letnim.

Lotność w warunkach stałego ciśnienia określa temperatura wrzenia, która w przypadku DMF wynosi $93,5^{\circ} \mathrm{C}$ (tabela 6). Natomiast lotność w warunkach stałej temperatury określa prężność par związku. DMF przy temperaturze $75^{\circ} \mathrm{C}$ odznacza się prężnością par równą $404 \mathrm{mmHg}$ (tabela 6). Po przeliczeniu wynik ten daje około $53,9 \mathrm{kPa}$, a więc w odniesieniu do aktualnych wymagań dla benzyn silnikowych, jest to wartość mieszcząca się w zakresie tolerancji.

Kolejną ważną własnością benzyn jest odporność na spalanie stukowe. Spalanie stukowe to zjawisko występujące w pewnych warunkach pracy silnika, polegające na gwałtownym wzroście szybkości spalania, który powoduje powstanie dodatkowej fali ciśnienia o częstotliwości w zakresie słyszalnym. Objawia się to występowaniem w cylindrze silnika charakterystycznych dźwięków metalicznych, tzw. stuków.

Spalanie stukowe jest bardzo niekorzystne, ponieważ nasila nierównomierność przy pracy silnika zmniejszając jego sprawność. Ponadto powoduje wzrost zużycia paliwa i przegrzewanie się elementów silnika.

Odporność na spalanie stukowe związków chemicznych (w tym paliw) charakteryzuje liczba oktanowa. Liczbę tą określa procentowa zawartość izooktanu (którego odporność na spalanie stukowe wynosi 100 jednostek) w mieszaninie z n-heptanem (którego odporność na spalanie stukowe wynosi 0), która w warunkach normalnych badania ma taką samą odporność na spalanie stukowe, jak badane paliwo. Im większa jest liczba oktanowa benzyny tym większa jest jej odporność na spalanie stukowe. DMF ma liczbę oktanową równą 119 (tabela 6), a więc jego odporność na spalanie stukowe jest bardzo wysoka. 
DMF należy do organicznych związków tlenowych - w cząsteczce zawiera atom tlenu obok atomów węgla i wodoru. Związki te przy zachowaniu wymagań dotyczących ochrony środowiska zapewniają dobre właściwości przeciwstukowe, a więc charakteryzują się wysokimi wartościami liczb oktanowych.

Przy istniejących silnikach spalinowych o zapłonie iskrowym, w których stosuje się benzyny o liczbie oktanowej rzędu 95-98 (E95 lub E98), czysty DMF nie mógłby być stosowany z uwagi na jego zbyt wysoką liczbę oktanową. Jednakże w przypadku zastosowania go jako biokomponentu do paliw, bądź też biopaliw, może on skutecznie podwyższać odporność na spalanie stukowe mieszanki paliwowej.

Następnym istotnym parametrem paliw do silników o zapłonie iskrowym jest gęstość energetyczna zwana również wartością opałową. Własność ta określona jest poprzez ilość energii zmagazynowanej w jednostce masy, bądź w jednostce objętości paliwa. Oznacza to, że do uzyskania tego samego efektu energetycznego potrzebny jest wtrysk mniejszej ilości paliwa o relatywnie wyższej gęstości energetycznej.

Parametr ten, w przypadku związków węglowodorowych jak i związków tlenowych, zależy od atomów wodoru i atomów węgla oraz od budowy cząsteczki. Wartość opałowa jest tym większa, im większa jest wartość stosunki wodoru do węgla, ponieważ wodór jest najbardziej energetycznym pierwiastkiem $\left(\mathrm{W}_{\mathrm{o}}=120\right.$ $\mathrm{MJ} / \mathrm{kg}$ - wartość opałowa węgla, $\mathrm{W}_{\mathrm{o}}=32,7 \mathrm{MJ} / \mathrm{kg}$ ). Ponadto wysoka zawartość wodoru w paliwie jest korzystna także w aspekcie ochrony środowiska, gdyż oprócz mniejszego zużycia w spalinach silnika jest mniej $\mathrm{CO}_{2}$ (i CO), a więcej wody.

Gęstości energetyczne poszczególnych substancji paliwowych przedstawia tabela 7.

Tabela 7. Porównanie gęstości energetycznych poszczególnych paliw i biopaliw ${ }^{12}$

\begin{tabular}{|c|c|c|c|c|}
\hline \multirow{3}{*}{ SUBS囚ANCJA } & \multicolumn{4}{|c|}{ GĘS凶OŚC ENERGE凹YCZNA } \\
\hline & \multirow{4}{*}{$\begin{array}{c}\text { w masie } \\
\text { JEDNOS区KA }\end{array}$} & & \multirow{4}{*}{$\begin{array}{l}\text { w objętości } \\
\text { JEDNOS凶KA }\end{array}$} & \\
\hline & & WAR囚OSĆ & & WAR冈OSĆ \\
\hline Benzyna & & 46,9 & & 34,6 \\
\hline ON & & 45,8 & & 38,7 \\
\hline Płynny wodór & \multirow{4}{*}{$\mathrm{MJ} / \mathrm{kg}$} & 143 & \multirow{4}{*}{$\mathrm{MJ} / \mathrm{l}$} & 10,1 \\
\hline Gazowy wodór & & 143 & & 0,01 \\
\hline LPG propan & & 49,6 & & 25,3 \\
\hline LPG butan & & 49,1 & & 27,7 \\
\hline Etanol & & 30 & & 24 \\
\hline DMF & & 42 & & 37,8 \\
\hline
\end{tabular}

${ }_{12}$ http://en.wikipedia.org/wiki/Energy_density 
Gęstość energetyczna DMF wynosi $42 \mathrm{MJ} / \mathrm{kg}$ i $37,8 \mathrm{MJ} / \mathrm{l}$ (tabela 7). Jest to wynik korzystny na tle etanolu, którego wartości gęstości energetycznej wynoszą $30 \mathrm{MJ} / \mathrm{kg}$ i $24 \mathrm{MJ} / \mathrm{l}$ (tabela 7). Ponadto można powiedzieć, że pod względem tego parametru DMF może być godnym substytutem benzyny, gdyż wartości ich gęstości energetycznych są zbliżone (benzyna: $46,9 \mathrm{MJ} / \mathrm{kg}, 34,6 \mathrm{MJ} / \mathrm{l}$ ).

DMF w swej cząsteczce zawiera jeden atom tlenu - jego wzór sumaryczny to $\mathrm{C}_{6} \mathrm{H}_{8} \mathrm{O}$. Przy masie cząsteczkowej $96,12892 \mathrm{~g} / \mathrm{mol}$, tlen stanowi $16,64 \%$ masy cząsteczki. Jest to wartość zbyt wysoka w stosunku do wymagań dla paliw stosowanych w silnikach ZI.

DMF jest związkiem stabilnym chemicznie, ze względu na trwałość pierścienia furanowego, co jest zaletą względem eksploatowania go w silnikach spalinowych pojazdów, jak i względem długotrwałego magazynowania.

Parametry takie jak zawartość benzenu, związków siarki i ołowiu nie dotyczą DMF, ponieważ nie zawiera on w swej budowie ani pierścienia benzenowego, ani też siarki i ołowiu, co również stanowi jego zaletę.

Przewiduje się, że ze względu na bardzo korzystne właściwości eksploatacyjne i ekologiczne, w przyszłości DMF może okazać się komponentem tlenowym powszechnie stosowanym w składzie paliw do napędu silników o zapłonie iskrowym.

Najbardziej perspektywicznym surowcem wyjściowym będzie odpadowa celuloza, której duże ilości znajdują się między innymi w słomie i odpadach drzewnych, a także odpadowa skrobia, jak również inne surowce odnawialne, zawierające polisacharydy. DMF produkowany z tych surowców może być w $100 \%$ uznany za biopaliwo drugiej generacji. Polska dysponuje dużymi faktycznymi oraz potencjalnymi zasobami surowców, które mogą być wzięte pod uwagę jako surowce wyjściowe do produkcji DMF. Jak dotychczas zasoby te są użytkowane nieracjonalnie.

DMF można dodawać do benzyny węglowodorowej jako komponent tlenowy, a jego stosowanie w składzie benzyny silnikowej nie wymaga żadnych zmian w konstrukcji silników, układów zasilania oraz systemów dystrybucji.

Jednakże rozwój DMF jako biokomponentu silnikowego wymaga niestosowanych jak dotychczas przemysłowych rozwiązań technologicznych, głównie w sferze procesów mikrobiologicznych.

\section{Wnioski}

冈echnologie produkcji DMF są na bardzo wczesnym etapie rozwoju. Dlatego postuluje się podjęcie prac badawczych zmierzających do rozpoznania przemysłowej produkcji DMF w Polsce. Oto i niektóre cele tych prac:

- ocena przydatności różnych dostępnych w Polsce surowców do produkcji DMF; 
- standaryzacja DMF;

- budowa instalacji $1 / 4$ przemysłowej przy uwzględnieniu badań laboratoryjnych;

- przeprowadzenie badań laboratoryjnych nad różnymi wariantami otrzymywania DMF;

- szczegółowe badania właściwości eksploatacyjnych DMF;

- ocena DMF jako komponentu benzyny silnikowej;

- ocena ekonomiczności produkcji DMF na skalę przemysłową;

- opracowanie promocyjnych uwarunkowań prawnych i fiskalnych DMF.

Głównym celem tych prac powinno być opracowanie końcowych postulatów w związku z celowością inwestycji przemysłowego uruchomienia produkcji DMF przy szczegółowym określeniu surowców, dostępnych w Polsce.

Uruchomienie produkcji DMF z celulozy, skrobi itd. pozwoliłoby Polsce na częściowe spełnienie zobowiązać względem Unii Europejskiej, które wynikają z Dyrektywy 2003/30/WE zwanej potocznie „paliwową", a także na racjonalne wykorzystanie odpadów celulozowych, skrobiowych, a także biomasy.

\section{LIDERAXURA}

J. GŁĄB, W. GóRsKI, DMF - nowa koncepcja paliwa silnikowego z polisacharydów, konferencja „Perspektywy Biopaliw Silnikowych II Generacji w Polsce Polbiof 2007” (materiały konferencyjne), Kraków 24-25.10.2007,

I. M. Heilebron, E. R. H. Jones, Improvements in or relating to Process for the Manufacture of 2,5-Dimethylfuran and Acetyloacetone, Provisional Specification No: GB61 1072, London 1948,

I. M. Heilebron, E. R. H. Jones, Process for the manufacture of 2,5-dimethylfuran and acetonylacetone, Patent No: US2470070, London 1946,

K. Baczewski, 囚. KA£Doński, Paliwa do silników o zapłonie iskrowym, Wydawnictwa Komunikacji i Łączności, Warszawa 2005,

L. JANowicz, Potencjał energetyczny odpadów, Trzecie Regionalne Forum Energetyki Odnawialnej, Przysiek 18.05.2007,

A. Sivasamy, P. Foransiero, S. Zinoviev, BIO-FUELS: Technologies Status and Future Trends, Feedstock and Product Valorization, Assessment of Technologies and DSTs, ICS-UNIDO, Ørieste (Italy) 28 June 2007,

Y. Leshkov, C. Barret T, Z. LiU, J. Dumesic, Production of dimethylfuran for liquid fuels from biomass-derived carbohydrates, Nature vol. 447 (21 June 2007), s. 982-985,

Y. Leshkov, C. Barret T, Z. LiU, J. Dumesic, Production of dimethylfuran for liquid fuels from biomass-derived carbohydrates, Supplementary Information, doi: 10.1038/nature05923,

CRC Handbook DMF; www.sciencedaily.com/releases/2007/06/070620154945.htm,

2,5-Dimethylfuran, http://en.wikipedia.org/wiki/Dimethylfuran,

Rozporządzenie Ministra Gospodarki, Pracy i Polityki Społecznej z dnia 23 grudnia 2003 r. w sprawie wymagań jakościowych dla paliw ciekłych. 


\title{
DMF (2,5-dimethylfuran) as a perspective of second generation biofuel in spark ignition engines
}

\author{
SUMMARY
}

One year ago there turned out the first scientific publications about obtain possibilities of 2,5-dimethylfuran (DMF) straight from fructose, from raw materials like cellulose, starch or fruits. According to some sources, DMF could be use like oxygen fuel component, because of its properties.

In this article were discussed physical and chemical properties of DMF, and raw possibilities to DMF production as a second generation biofuel. There were also discussed possible technologies of DMF obtaining in "Wisconsin-Madison" technology. Besides there was performed an estimation of DMF application possibilities in present internal combustion engines. 